\title{
Sacral rulers in pre-Christian Scandinavia: The possibilities of typological comparisons within the paradigm of cultural evolution ${ }^{1}$
}

SIMON NYGAARD

Aarhus University

\begin{abstract}
This article offers a new perspective on the century-old discussion of sacral rulers in the history of religions generally, and pre-Christian Scandinavian religions specifically, namely the application of a cultural evolutionary theoretical framework based on the work of Robert N. Bellah. In doing this, the article opens the possibility of wider typological comparisons within this paradigm and suggests a nuancing of Bellah's typology with the addition of the category of 'chiefdom religion'. This is utilised in the main part of the article, which features a comparison between the figure of the sacral ruler in pre-Christian Scandinavian and pre-Christian Hawaiian religions through an analysis of: 1 ) the position of the ruler in society, cult, and ideology; 2) the societal structure in which these religions are found; 3) the idea of a ruler sacrifice; 4) incestuous relationships and their ideological implications; and, finally, 5) the idea of a double rulership. Following this comparison, the perspectives in and the usefulness of cultural evolutionary theories in the history of religions are briefly evaluated.
\end{abstract}

Keywords: sacral rulers, sacral kingship, pre-Christian Scandinavian religions, pre-Christian Hawaiian religions, Robert N. Bellah, cultural evolutionary theory, cultural evolution, typological comparison, chiefdom religion.

The idea of sacral kingship is well-established in the history of religions, dating back to the late 19th century and James George Frazer's The Golden Bough: A Study in Comparative Religion (1890). ${ }^{2}$ Since Frazer several scholars within the field of pre-Christian Scandinavian religions have discussed the idea of a sacral kingship in pre-Christian Scandinavia and the Germanic

1 This article is based largely on research done for my Master's thesis (Nygaard 2014).

2 Frazer's methodology has been much criticised - and rightly so. His comparativism was almost arbitrarily self-defined because of his unconstrained global use of sources, which is a problem for modern day historians of religions. 
area. This article offers a new perspective on the discussion through the application of a cultural evolutionary theoretical framework. This application enables new typological comparisons of pre-Christian Scandinavian religions with religions of the same type, for instance, with pre-Christian Hawaiian religions as in this article, shedding new light on sacral rulers in pre-Christian Scandinavia.

Through the application of cultural evolutionary theory certain characteristics within pre-Christian Scandinavian religions, culture, and society relating to the figure of the ruler will be revealed, examined, and compared with pre-Christian Hawaiian religions to demonstrate the usefulness of cultural evolutionary theory as a comparative and analytical tool in the creation of models for reconstruction in the history of religions.

\section{Theory and method}

The specific cultural evolutionary theory which I will apply in this article was proposed by the recently deceased (July 2013) American sociologist of religion, Robert N. Bellah. In his magnum opus, Religion in Human Evolution: From the Palaeolithic to the Axial Age (2011), he outlines the evolution of religion as a deep history spanning everything from the Big Bang until the present time. He does not present a history of single temporal and geographical foci in different religions, but a general, convergent religious evolution (Jensen 2013, 11-2). In this perspective evolution not only concerns genes but also entire organisms and cultural systems; this draws on both Roy Rappaport's systems theoretical 'adaptive structures' (Rappaport 1979, 145-7) and Clifford Geertz's classic definition of religion $(1973,90)$.

Cultural evolution is seen as a biocultural coevolution, where religion is an inherent part of the evolution of the human mind along with, for instance, language as an element of culture. Within this cultural evolutionary framework it is reasonable to assume that religion may exist in distinctive types, corresponding with particular cultural historical phases, which simultaneously correlate with changing economic, social, and political-framework conditions. Importantly, when working with cultural evolution, these distinctive types of religion are characterised by an accumulation rather than a dismantling. Bellah puts it this way: 'Nothing is ever lost' (2011, 267), meaning that traits of less complex religions can still be found, even in very complex religions.

Utilising the above, Bellah proposes a convergent evolutionary typology of religion, comprising these distinctive types of religion. The basic structures 
of this typology correlate with and are inspired by neuroscientist Merlin Donald's four-phase typology for the evolution of consciousness (2001). Bellah's typology comprises five types of religion: tribal, archaic, axial, early modern, and modern. I shall not discuss the last three types any further in this article, but they are discussed at length by Bellah ((2011, 265-606) for axial religions and (1964, 368-74) for early modern and modern religions). Of Bellah's types of religion, it is the pre-axial that is the most interesting for this article's purposes.

1) Tribal religion is characteristic of hunter-gatherer societies. Such societies are often nomadic and tribal, characterised by egalitarianism and a mechanical solidarity concerning the division of labour. The cosmological universe of the tribal religion is monistic and dedicated to supernatural beings with a relatively fluid identity, and a pantheon proper has yet to form. Bellah emphasises that supernatural beings in tribal religion are often theriomorphic. However, his emphasis may be too strong: there are also many examples of anthropomorphic supernatural beings in tribal religions. ${ }^{3}$ As in society, rituals are egalitarian, and as a rule the entire tribe takes part. The use of ritual or religious specialists is limited to those, like shamans, who are more in touch with the spirit world and better equipped to lead the tribe in a ritual that ultimately benefits the entire tribe (Bellah 1964, 361-4, 2011, 117-74).

2) Archaic religion is a feature of the early states from the great river valley civilisations of the ancient Near East. They presuppose urbanisation, a polity with a marked hierarchical structure, and craft literacy. The division of labour tends towards a more organic solidarity, where specific groups take care of specific tasks and crafts. The cosmological universe, which can now accurately be termed a mythology, is still monistic and consists of a pantheon of anthropomorphic gods with a personality, gender, and approximate age. The distinctive rituals of this type of religion are handled by a specialised priesthood. In these societies monumental temples are built, as seen in Egypt and in the Mayan and Aztec societies in Central and South America. In archaic religion the ruler has a strong connection to the gods, and is often seen as a divine or semi-divine being (Bellah 1964, 364-6; 2011, 210-64).

According to Bellah, these are the two types of religion present in predominantly oral societies. However, some religions seem not to fit these categories, pre-Christian Scandinavian religions included. Society in preChristian Scandinavia was not archaic because of its lack of polity and

3 For example, the Inuit sea goddess Sedna, the Winnebago Earthmaker, and the creator god from French Polynesia, Ta'aroa, all have both human and animal traits. 
urbanisation. An example is Hedeby, ${ }^{4}$ which was the largest settlement in Scandinavia in the Viking Age, with a population of c. 1,500 (Skre 2012, 84). Grave finds also suggest a more tribal form of society, with the family as the locus, and not the heavily stratified, urbanised society implied by archaic society. Of course, stratification is found, as we shall see later, but there is no urbanisation. Does this mean that society in the Iron and Viking Age North was tribal? This is not necessarily the case. When Caesar, in De Bello Gallico (c. 50 BC), describes the Germanic warlord Ariovistus as having 15,000 people in his retinue, this suggests a form of hierarchical societal structure not found in tribal societies. This may be explained as the result of cultural interchange with archaic cultures like the Celts (Egeler 2013, Enright 1996). However, this is not the only possibility. I will present another plausible explanation, namely, that pre-Christian Scandinavian religions might be conceived of as 'chiefdom religions's.

The transition from tribal to archaic religion may be more than just a transition. In this article I shall explore the possibilities of nuancing Bellah's typology.

\section{The sacral ruler - a brief research history}

The discussion concerning the sacrality of rulers in pre-Christian Scandinavia has existed for many years. Some scholars in the early 20th century sought to prove the existence of a sacral kingship in pre-Christian Scandinavia (see Von Friesen 1932-34; Höfler 1952; F. Ström 1954; Å. V. Ström 1959), while later scholars simply aimed to refute it (see Baetke 1964; Picard 1991). In recent years the idea of categorically accepting or refuting the existence of a sacral kingship has been replaced by reflections for or against. This has been prompted by the increasing methodological awareness within the field (Nygaard 2013, 137-9), which has been a catalyst for research, especially within the history of religions, that has explored the possibility of some form of sacral or religious ruler-figure in pre-Christian Scandinavia (Schjødt 1990; 2010; Steinsland 1991; 2000; Sundqvist 2002; 2012) - research which I will draw on throughout this article's analysis.

4 Of course, society in pre-Christian Scandinavia was neither uniform nor coherent, and Hedeby is not representative of the entire area, but serves only as an example of the lack of urbanisation.

5 Bellah $(2011,175-210)$ treats two Polynesian societies, Tikopia and Hawaii, as transitional societies between the tribal and archaic categories, but with a lack of stringency. I seek to remedy this by suggesting the establishment of the category of chiefdom religion. Similar suggestions have been made by Bernhard Lang (2013) and Turner \& Maryanski (2008). 
The earliest scholars all but took it for granted that a sacral kingship existed in pre-Christian Scandinavia (Å. V. Ström 1959, 702; F. Ström 1954, 35), while perhaps the most notable researcher into sacral kingship, Walter Baetke, did precisely the opposite (1964). He refuted the possibility of a sacral kingship having existed in pre-Christian Scandinavia entirely. Baetke's very source-critical approach is problematic to an historian of religions working with a model-based (re)construction of past religions (cf. Schjødt 2012a). Furthermore, a primary criticism of Baetke's theories has been the sharp distinction between kings and other social leaders without reference to important sources such as Háleygjatal (c. 885) and Frreyinga saga (c. 1215) in his conclusions (McTurk 1974-77, 150). Here, the wider definition of sacral rulership - or 'Religious ruler ideology', as Olof Sundqvist puts it (2012, 233-6) - as opposed to Baetke's strict definition, in which the king must be the object of a cult $(1964,39)$, seems more applicable, and will be the underlying understanding used throughout this article. It should also be noted that when comparable material from other cultures similar to preChristian Scandinavia is examined it would seem quite striking were the ruler not thought of as sacral to some degree, given that this is indeed the case in so many of these cultures (as Schjødt has commented (forthcoming)).

One such comparable culture is the pre-Christian Hawaiian culture, which will be the primary point of reference throughout this analysis. This comparison is possible because the two religions in question, as previously mentioned, seem to belong to the same type of religion in our cultural evolutionary typology of religion, chiefdom religion, and thus evince similar characteristics in societal structure, religious practice, and ideology, which the analysis will show. Indeed, the use of Bellah's theory makes this kind of typological comparison possible (see also Schjødt, forthcoming).

The themes I will address are: 1) the position of the ruler in society, cult, and ideology; 2) the societal structure in which these religions are found; 3) the idea of ruler sacrifice; 4) incestuous relationships and their ideological implications; and, finally, 5) the idea of a double rulership in chiefdom religion.

\section{The position of the ruler}

As previously mentioned, it is quite plausible that the ruler figure in preChristian Scandinavia possessed a certain degree of sacrality. As Jens Peter Schjødt $(1990 ; 2010)$ stresses, he occupied a special position in society through his numinousity, which had probably been given to him by the 
gods. This numinous power enabled the ruler to act as a mediator between men and gods. This is also seen in pre-Christian Hawaii, ${ }^{6}$ where the ruler was the main mediator between the gods and men through his handling and consecration of the human sacrifice which set him apart from the rest of the Hawaiian nobility, the alii, and also contributed to his special position in society (Valeri 1985, 140-2). It was through sacrifice that the pre-Christian Hawaiian gods granted the Polynesian equivalent of numinousity, mana, to the sacrificer (Goldman 1970, 218). The degree of mana was given in accordance with several factors, among them purity. Purity and completeness were signs of the divine and paramount in the acquisition and upholding of mana. The completeness of the ruler can be seen through the autonomy of the alii, as their endurance did not depend on anyone from outside their family and social stratum. This was exemplified by incestuous relationships, which I will consider later. Purity and its upholding was perhaps the most important means of acquiring sacrality in pre-Christian Hawaii. The pure and the impure related to each other as life and normativity to death and the loss of integrity. As the loss of this bodily integrity correlated with the loss of social integrity, the juxtaposition between the pure and impure functioned as a social status marker. Purity was thus a marker of the normativity and completeness of which the ruler and the gods were representatives. If the ruler lost his purity through war, for example, he could restore it and his social status through sacrifice, in which he gained mana and numinousity (Valeri 1985, 84-6, 146-8).

How, then, was this numinousity bestowed on the ruler in pre-Christian Scandinavia? Two possible ways are found in the sources: through inheritance and through initiation. These two kinds of ruler can be termed hereditary and elective. This ties in with the idea of double rulership, to which we shall return in due course.

The idea that initiation played a major role in pre-Christian Scandinavian religions, and notably in the ideology of the ruling elite, has been convincingly described by Schjødt (2008). In connection with the ruler's numinousity, it is likely that he was initiated in order to gain the knowledge and abilities needed to rule. This initiation may have been used in combina-

\footnotetext{
6 Valerio Valeri (1985) synthesises the sources for pre-Christian Hawaiian religion. These sources are normally catagorised into 1) eye witness accounts from pre-contact times until the Cultural Revolution in 1819 recorded by early Hawaiian scholars such as David Malo (1903); 2) sources written by Christian missionaries; and 3) sources from European seafarers. As is the case with pre-Christian Scandinavian religions, it is predominantly the religion of the elite which is recorded - and in Hawaii often through the lens of colonial Christians.
} 
tion with inheritance, and the hereditary ruler may have been initiated to Óðinn in order to perform his duties as a ruler.

The idea of divine descent can be seen in Tacitus's Germania 2 (c.100 CE), where he writes that all the peoples are descendants of the gods. This may be taking it too far, but a reasonable assumption would be that those in the highest social stratum were seen as divine descendants (Schjødt 1990, 57-62).

Various traditions concerning rulers' divine descent can be found in our sources. In different parts of pre-Christian Scandinavia and in the Germanic and Anglo-Saxon areas rulers traced their lineage to different gods. In the majority of cases the role of progenitor was taken by either Óðinn or Freyr. The most famous example of divine descent is probably the Ynglingar of Gamla Uppsala, who traced their lineage to Freyr. This is described in the 9th century skaldic poem Ynglingatal, in which expressions like 'Freyr's descendant' (Freys áttungr) and 'Freyr's offspring' (Freys afspringr) can be found. These textual attestations are thought to portray the idea of divine descent quite clearly.

Another well-known example of the divine ancestry of a line of rulers is the jarlar of Hlaðir in Norway. In the skald Eyvindr skáldaspillir's poem Háleygjatal from c. 885 their lineage is traced to jarl Sæmingr, who was the son of Óðinn and the jotunn woman Skaði, and as such a divine ancestor. In another skaldic poem from around 990, Vellekla, Óðinn is mentioned as the ancestor of jarl Hákon: in stanza 20 he is described as 'generous relative of Ygg [Óðinn]', (fémildr Yggs niðr) (Sundqvist 2012, 240-1).

One of the jarlar in Háleygjatal is also called Freys ottungr, which may simply mean divine descendant, while Snorri writes that the Hlaðajarlar are descendants of Yngvifreyr or Ingunarfreyr. Some scholars have taken this to mean that Freyr was the original ancestor of the Hlaðajarlar, and that the idea of Óðinn being their ancestor must be an influence from Western and Continental Europe, i.e. from Anglo-Saxon tradition. This need not be the case, but in any event the underlying idea seems to be of the rulers' divine descent.

The Anglo-Saxon traditions also feature either Óðinn- or Freyr-like gods in their royal lineages. In Bede's 8th century Historia Ecclesiastica Gentis Angolorum Óðinn features as Wodan, while a Freyr-like god could be behind the names Saxnot and Ing (cf. North 1997). This, however, is widely debated.

The idea of the sacrality and numinousity of the ruler gained through sacrifice, initiation, and divine descent thus seems a prominent feature of both religions. 


\section{Societal structure}

Through both the Iron and Viking Ages pre-Christian Scandinavia consisted of a variety of more or less organised societies, like those around Lejre in Denmark (Christensen 2012, 121-5) and Mälaren in Eastern Sweden, the land of the Svear (Hyenstrand 1996: Sundqvist 2002). The latter will serve as a tentative example of the societal structure of pre-Christian Scandinavia.

In the area around Lake Mälaren archaeological finds show continuity in habitation from the Bronze Age to the Modern Era. Finds from the Bronze Age bear witness to something similar to chiefdoms and trade, and the import of high quality goods can be established. Through the Iron Age a more organised society can be found, supported by cattle husbandry and early agriculture, as well as hunting and fishing (Roesdahl 2010, 96, 102). This, along with the production of iron and the working of gold, provided the foundation of trade in the area in the Iron and Viking Ages (Hyenstrand 1974). Not much in the way of writing existed in Scandinavia before the advent of Christianity. Runic inscriptions can be found as early as the 2nd or 3rd centuries CE and are more widespread in the Viking Age, but this does not mean that society in pre-Christian Scandinavia was literary. These runic inscriptions are for the most part short texts carved in wood, stone, or metal, some featuring names of gods and cultic leaders or curses, invocations, or incantations; but more often they relate simply who made them, for whom, and why (McKinnell et al. 2004). The Latin alphabet was brought to Scandinavia by Christian missionaries, along with the use of parchment and ink.

Society in pre-Christian Hawaii consisted of various more or less autonomous chiefdoms throughout the archipelago. On each island one paramount chief ruled over the others, leading to much warring between chiefdoms to gain this position of power. This structure was displaced in 1810, when the first Hawaiian king, Kamehameha I, unified Hawaii. Economically, preChristian Hawaii was quite simple: it was sustained through horticulture, the raising of poultry, swine, and dogs, and through aquaculture (Kirch 1984, 181-4). No writing can be found, and compared with the rest of Polynesia the architectural achievements are mediocre (Goldman 1970, 200). The remarkable feat of pre-Christian Hawaiian society lies in its bureaucratic and administrative development and the specific social system. The stratified class system found in pre-Christian Hawaii is probably one of the main reasons for the development of the complex, warrior-like chiefdoms and eventually the kingdom of Hawaii (Bellah 2011, 198). 
Grave finds from Late Iron Age Eastern Sweden give a picture of a more stratified society than was previously the case, and the existence of a ruling warrior-elite may be discerned from this point on. This is more marked in the Viking Age, as finds throughout Scandinavia have shown (Price 2012, 32-42). Society was kinship-based and bilateral, with a slight paternal skewing (Sundqvist 2002, 64). In the Iron Age the area around Mälaren constituted a decentralised society divided into districts led by independent leaders or rulers. Names like Arland, Valand, and Soland indicate such districts (Brink 1996; 1997), which may have been a form of chiefdom. In Iron Age society central places like Gamla Uppsala seem to have played a significant role as seats for local rulers, often acting as primus inter pares among the other rulers in the area. In time, through a process of centralisation, these chiefdoms were united in a form of socio-political unit - a large chiefdom or, eventually, a petty kingdom. This may be the Svearike or Svitjod of the sources. Both archaeological and written sources point to Gamla Uppsala as the central place of Svearike, as names of different parts of the area seem to refer to their placement relative to it. This process of centralisation may have been the result of ideological changes in the ruler ideology. Through the Iron and Early Viking Ages the rulers seem to have been hierarchically equal, with the ruler in Gamla Uppsala acting as primus inter pares, as previously mentioned. In Ynglinga saga 36 (c. 1230) it is said that 'Ingjald son of King Anund became king in Uppsala. The Uppsala-kings were the most eminent of kings in Svitjod when there were many kinglets there.' The development towards one paramount ruler seen in the Late Viking Age and Early Middle Ages may be the motif behind the further narrative in Ynglinga saga 36, where King Ingjald invites the rulers of Svitjod to the old King Anund's wake. In the night, when all the rulers are drunk, Ingjald burns down the hall in which they are sitting and thus gains power over all their lands. The essence of this narrative may be inspired by the change in ruler ideology - from hierarchically equal rulers, with the Uppsala ruler acting as primus inter pares, to the Uppsala ruler as the paramount ruler (Sundqvist 2002, 65-72; 2016).

In pre-Christian Hawaii a ruling elite, the alii, also existed. There could be no genealogical contact between the alii and the common people. This is why a peasant was not allowed to trace his family more than three generations back, while the alii were required to be able to trace their lineage ten generations back, as well as to be able to prove a blood bond between them and the paramount ruler (Bellah 2011, 198). In pre-Christian Hawaii status was gained through genealogy, but these genealogical questions also had the function of a political alliance, as it was the ruler in power who had to 
approve and acknowledge the genealogies of his supporters in the rest of the alii once he had gained power.

What we seem to see here are two different kinds of chiefdom, both gradually developing into what one could term petty kingdoms or very early territorial states (see Trigger 2003, 92-119; Bellah 2011, 213). With the coming of Christianity in the late 1770s, the long-held ambition of a united kingdom of Hawaii became reality with the aid of some European seafarers (Goldman 1970, 203). Larger kingdoms, like Haraldr blátǫnn's 10th century Denmark, also began to form in Scandinavia, probably in the late Viking Age, assisted in various ways by the coming of Christianity. ${ }^{7}$

\section{Ruler sacrifice}

In pre-Christian Scandinavia signs of human sacrifice have been found in connection with wetland areas. This archaeological evidence suggests that these sacrifices were collective offerings of an enemy army (Sundqvist 2002, 72; Andrén 2014, 90-8). Early Iron Age bog bodies such as Grauballemanden and Tollundmanden have been found, suggesting that some humans may have been individually sacrificed. ${ }^{8}$

In pre-Christian Hawaii human sacrifice seems to have been a much more integral part of the ritual system. The luakini ritual, which helped tame and purify the paramount ruler, was a human sacrifice. Indeed, only the paramount chief could authorise such a human sacrifice, a ritual in which he was sacrifier, sacrificer, and sacrifice (Bellah 2011, 202). I shall return to this shortly.

This leads us to the notion of ruler sacrifice. Is it possible that the ruler was a viable sacrifice in chiefdom religion? We will begin with examples from pre-Christian Scandinavia.

Direct archaeological evidence of ruler sacrifices in pre-Christian Scandinavia has not been found. However, written sources do mention rulers who have been sacrificed. These written sources are not, of course, historically accurate, but we can at least assume that they portray ideas and conceptions that may have been part of pre-Christian ruler ideology (see Schjødt 2012a). Here, I will use the sources about King Dómaldi's death and the sacrifice of King Víkarr.

7 This development is, of course, also historical, but the understanding of evolution used in this article does not exclude the influence of such external factors (cf. Petersen 2013, 69-71). 8 P.V Glob (1969) suggests the bog bodies were sacrifices for the gods, while Anders Hultgård (2001) refutes the sources for human sacrifice altogether. 
Ynglinga saga 15 tells the story of King Dómaldi of Svitjod, under whose rule famine and hardship led the Svear to hold a large ritual (blót) in Uppsala. The first autumn they sacrificed oxen; the next they sacrificed humans (mannblot); but the season did not improve. The third autumn the chieftains gathered to hold council and agreed that the famine was due to King Dómaldi, and that they should sacrifice him for better seasons (blóta til árs sér), which they did. The narrative in the considerably older (c. 900) Ynglingatal 5 is almost the same. Dómaldi is sacrificed (sóa) by his own people because they are eager for crops (árgiarn), while the 13th century Latin work, Historia Norwegix, relates how Dómaldi was hanged as a sacrifice to Ceres. Ceres in usually thought to be an interpretatio romana for Freyja, both being fertility goddesses per se (Sundqvist 2002, 241-50). Although the sacrifice of King Dómaldi has been variously interpreted through the years, one thing seems certain: the idea of a ruler sacrifice seems to be genuinely preChristian, and the age of Ynglingatal lends weight to this claim. The reason behind Dómaldi's sacrifice seems to be the same in all three instances. The harvest has failed, and the people try to re-establish the proper order of the world by maintaining the ritual coherence. If they do not, the world will suffer and eventually come to an end. This ritual immanence is a common trait in ritual and cult based cultures (Assmann 2006, 126). In this example the sacrifice of Dómaldi restores order by securing the land's fertility. The function of the ruler as the mediator between gods and men had not been fulfilled by Dómaldi, so sacrifices had to be made. Why then was Dómaldi ultimately chosen when all other sacrifices had failed to work? The answer is likely to be found in the sacrality and numinousity of the ruler, as previously discussed. The object to be sacrificed to the gods has to be made sacral in the process, and if the ruler is already sacral and is possessed of more numinousity than other humans, then he is better suited for sacrifice than others (Schjødt 2010, 174).

In the fornaldarsaga Gautreks saga 7 (late 1200s) and in Saxo's 12th century Gesta Danorum 6, 5,1-8, 8,12 another ruler sacrifice is described. The sacrifice of King Víkarr by the warrior Starkaðr is described similarly in both sources. Here, I will use Gautreks saga. King Víkarr, Starkaðr and the rest of the king's retinue are plagued by a strong headwind while on a raid. To change the wind, they try casting lots (fella spán), and it is augured that Óðinn demands a sacrifice by hanging by the drawing of lots. The king's lot is drawn. During the night Starkaðr's foster father, Hrosshárs-Grani, who is really Óðinn in disguise, comes to take Starkaðr away to a forest, where Óðinn and Pórr decide Starkaðr's fate. For the help Óðinn gives Starkaðr 
in this, Óðinn demands that Starkaðr give him King Víkarr as a sacrifice. Óðinn gives Starkaðr a spear, reassuring him that it will look like a reed stem. Starkaðr is to use this in a mock sacrifice resulting from the council's decision to give the king to Óðinn. The king does not think it dangerous and lets 'fate decide what happens' (auðna ráda, hvat sem gerist). The mock noose is put around his neck, and Starkaðr thrusts the reed stem into him saying, 'Now I give you to Óðinn' (Nú gef ek pik Óðni), at which point the stem becomes a spear and the mock noose a strong rope, and the king dies.

Now, many elements of this ruler sacrifice are interesting. It seems to be an Odinic sacrifice, with all its characteristic hallmarks. Óðinn is said to be able to 'turn the wind whichever way he want[s] to' (snúa vindum hverja leið, er hann vildi) (Ynglinga saga 7), and it seems reasonable for King Víkarr's men to sacrifice to Óðinn in their situation. As for the actual sacrificial act, the connections to Óðinn are many. Hanging seems to be strongly associated with Óðinn throughout the Old Norse text corpus. The Eddic poem, Hávamál 138-41, (probably composed between the 9th and 10th centuries) describes how Óðinn, 'wounded by spear' (geir undaðr), hanged himself, sacrificing 'myself to myself' (siálfr siálfom mér) in order to gain the numinous knowledge of the runes, a passage often called Óðinn's self-hanging. He is also said to be the 'lord of the hanged' (hangadrottinn) in Ynglinga saga 7, and in Hávamál 157 he relates how, by carving runes, he can wake a 'dangling hanged man' (váfa virgilnár). The spear also has strong connections to Óðinn. He uses a spear to institute 'the first war in the world' (enn fólkvig / fyrst $i$ heimi) (Voluspá 24 (c. 9th century) in illo tempore, while Ynglinga saga 9 tells of how on his deathbed he is marked with a spear in order to dedicate all men who die by a weapon to himself. Furthermore, the way in which Óðinn procures the sacrifice of Víkarr seems characteristic of this god. Using cunning and a false identity, he assists his hero, Starkaðr, giving him Odinic gifts, and in return he gains another great ruler and warrior for his army in Valhǫll. As with Dómaldi's death, Víkarr is a potent sacrifice because of his numinousity, and also a desirable addition to Óðinn's army of einherjar.

These two ruler sacrifices basically serve the same purpose. They are simple do-ut-des sacrifices given in order to remedy a situation, but they are given to two different gods with different functions. Dómaldi is sacrificed to secure the fertility of the land, possibly to Freyja, one of the collective of fertility gods known as the Vanir. ${ }^{9}$ Víkarr is sacrificed to Óđinn at his behest,

9 Recently, the term 'Vanir' has been much discussed. Some (Simek 2010) have argued for the abolition of the term; some (Frog \& Roper 2011) have sought a more balanced approach; others have been more positive towards it (Schjødt 2014; Tolley 2011). 
to turn the wind and the fortunes of the raid, while Óðinn possibly grants him a place of honour in his army of einherjar in Valholl (Schjødt 2010, 180). Fertility and war are thus juxtaposed in the two pre-Christian Scandinavian ruler sacrifices, a motif which seems ubiquitous in chiefdom religion.

As has been noted, human sacrifice was an integral part of pre-Christian Hawaiian ruler ideology. Very often it was blood relatives of the ruler who were sacrificed. It can therefore be seen as one of the 'fundamental symbolic conditions' of the religious system (Valeri 1985, 161). As in many other ritual-based cult cultures, in pre-Christian Hawaii sacrifices were made in order to uphold the relationship between the social hierarchy and the gods - a relationship in many ways essential for the upholding of established society (Valeri 1985, 165). The ruler, however, always ran the risk of being sacrificed himself. The war for power in pre-Christian Hawaii was almost never ending. The victorious chief was then elevated to divine status, while the pretenders to the throne were sacrificed to the god of war, Kü. Through this sacrifice the pretenders to the throne were absorbed into this deity. As all those who aspired to the throne and tried to claim it identified themselves with the ruler, they were structurally convergent with the ruler (Valeri 1985, 165). It was therefore symbolically the paramount ruler himself being sacrificed and absorbed into $\mathrm{K} \overline{\mathrm{u}}$, thus restoring the completeness and purity so essential to the pre-Christian Hawaiian religions, which had been disrupted by the violence of war. As previously mentioned, purity was a marker for normativity, of which the paramount ruler and the gods were representatives. To uphold the ruler's purity was to uphold his divine status (Valeri 1985, 84-6). In addition, by sacrificing his rivals, who were often either brothers or half-brothers, the paramount ruler could obtain their mana and genealogical rank, thus strengthening his claim to the throne (Bellah 2011, 203). It is here that the symbolic sacrifice of the ruler is connected with incestuous relationships in pre-Christian Hawaii. Indeed, incestuous relationships are an integral part of ruler ideology in pre-Christian Hawaii. I shall return to this having touched upon incestuous relationships in preChristian Scandinavia.

\section{Incestuous relationships}

Gro Steinsland (1991 passim) has posited that a hieros gamos motif was part of the ruler ideology in pre-Christian Scandinavia. In this connection it has also been suggested that the female in a sacred wedding may have been of the same blood as the ruler (Schjødt 2012b, 78). The hieros gamos can be 
viewed as an important part of the ritual and mythological cycle in many pre-axial religions (Lang 2013, 34-5 with references).

In pre-Christian Hawaiian mythology a hieros gamos-myth actually legitimises incestuous relationships. The feminine earth, Papa, is fertilised by the masculine sky, Wākea, and their first-born son becomes the important Hawaiian crop, the taro. In this myth the sacrifice is also instituted, which entails the separation of men and women in certain situations along with the establishment of kapu, the Hawaiian taboo. This separation enables Wākea the sky-god to sneak away during a night of separation to sleep with his daughter, whom he eventually marries. Wākea thus proves his autonomy, and that of all rulers who descend from him, and their independence from the traditional exogamous bridal exchange system, thus legitimising incestuous relationships. The myth shows that it is the sacrifice and the separation of the sexes that enable this, which, as we shall see, ultimately produces the heir to the throne (Valeri 1985, 169-71).

There may be remnants of this in the incestuous relationship of the Vanir in pre-Christian Scandinavia.

These incestuous relationships are mentioned several times in the Old Norse text corpus. In Ynglinga saga 4 we are told that while Njorðr was among the Vanir he was married to his sister. The offspring of this marriage were probably Freyr and Freyja, although its chronology is not entirely clear (see Hopkins 2012). They are also accused of incest in the Eddic poem Lokasenna 32 (composed $c$. 10th century), and Njorðr's relationship with his sister is also mentioned in Lokasenna 36, where Loki says that Njǫrðr had a son with her. This sister mentioned both in Ynglinga saga and Lokasenna may well testify to a tradition stemming back to the Iron Age. In Germania 40 Tacitus describes a procession ritual, in which the fertility goddess Nerthus is transported through the landscape in a ritual wagon, bringing joy and peaceful, festive days. A parallel to this is seen in Gunnars páttr Helmings in Flateyjarbók (late 14th century), where Freyr is driven through the landscape with a female priest in a wagon. This parallel, together with the fact that the functions of bringing peace and joy in connection with the landscape are those of the Vanir, makes it reasonable to view Nerthus as a Vanir-esque deity. There is also a linguistic connection between Nerthus and the Vanir. The Proto-Germanic cognate of both Nerthus and Njorðr is reconstructed as *nerpuz (power) (cf. Steinsland 2005, 147-9). This has given rise to the idea of Nerthus and Njorðr as divine twins, as is often the case with fertility deities, for instance the Nâsatyas of the Rigveda (c. 1900 BC). The names Freyr and Freyja also have a common root, meaning 'lord' and 'lady' in 
Old Norse, ${ }^{10}$ and the pair of siblings has been seen as a younger version of Njorðr and Nerthus, or *Njärð. ${ }^{11}{ }^{*} \mathrm{Njärd} \mathrm{is} \mathrm{a} \mathrm{reconstructed} \mathrm{name} \mathrm{based} \mathrm{on}$ Swedish place names, and has been posited as a possible Old Norse name for Nerthus by Britt-Mari Näsström (1995, 50-60), although the gender of *Njärd and indeed also * nerpuz is ambivalent (cf. Vikstrand 2001). Another possibility is the enigmatic goddess Njorun (Hopkins 2012).

If Nerthus/*Njärð is accepted as the sister-wife of Njorðr, the idea that legitimate incest is the motif behind the relationship mentioned in Lokasenna and Ynglinga saga and the relationship between Freyr and Freyja in Lokasenna is strengthened. The question remains: why? As previously mentioned, a hieros gamos with consanguine exigencies may have been the underlying motif. This may have been necessary to concentrate and accumulate the numinousity of the couple to facilitate the best possible outcome for the marriage, in this case, the fertility of the land. This accumulation is the basis of another example of incest in Old Norse literature.

This example is found in Volsunga saga 7 (late 13th century; however, the narrative was known as early as the 9th century, cf. the Ramsund carving), where the woman Signý uses seiðr to take the appearance of another woman to trick her brother Sigmundr into having sex with her. Sinfjotli, the son conceived through this relationship, gains all the positive attributes of the Volsungar, which enable him to avenge the killing of his grandfather King Volsung and his nine sons. This accumulation of qualities is similar to that seen in pre-Christian Hawaiian ruler ideology, where the mana and rank of the married couple is accumulated in their offspring; but what was inherent in pre-Christian Hawaiian society is only a mythical idea in preChristian Scandinavia.

As the kinship system in pre-Christian Hawaii was bilateral, with both sides carrying equal weight, finding an heir was a very complicated matter. This is why it was essential for the ruler to have the best possible genealogical claim to the throne. He therefore neutralised his negative, destructive male doubles with positive female equivalents, that is, sisters (Valeri 1985, 165). To secure the best possible genealogical claim to the throne, the paramount ruler had to monopolise as many women of high rank as possible. This was effected by incestuous relationships, which helped legitimise the genealogy of the ruler, and as the mana of both parents was accumulated in the offspring, they were then thought to be divine (Goldman 1970, 218).

10 Disputed by Lennart Elmevik (2003).

11 Other such name pairings may include Ullr and Ullinn, and Fjorgyn and Fjorgynn (Hopkins 2012). 
To retain this monopoly, the ruler had to sacrifice his rival brothers, and 'what begins as a fratricide must end as incest; the destruction of a brother must, through marriage with a sister, become the production of an heir. The negative double of the king is thus turned into a positive one.' (Valeri 1985, 165) This is also why human sacrifice in pre-Christian Hawaii was always ruler sacrifice, either symbolically, through the double's identification with the ruler, or literally, if the ruler had been dethroned (Bellah 2011, 202-3).

\section{Double rulership}

As previously mentioned, there seems to have existed a double rulership in pre-Christian Scandinavia, consisting of the hereditary ruler and the elective ruler. Tacitus may allude to this in Germania 7: 'They take their kings on the ground of birth, their generals on the basis of courage.' (Reges ex nobilitate, duces ex virtute sumunt.) Reges are here thought to refer to the hereditary rulers, and duces to the elective rulers - one ruler who was of the right family and one who had proven himself in battle. In the late Viking Age both aspects were seen in the same ruler, and the two roles have probably merged at a point in time (Schjødt 2012b, 79). This possible double rulership can also be seen in the mythology, where the two gods already mentioned as progenitors of the rulers in pre-Christian Scandinavia, Óðinn and Freyr, are representatives (Schlesinger 1956).

Freyr can be seen as the prototypical ruler in times of peace, the hereditary ruler, while Óðinn is the kind of ruler preferred in times of war, the elective ruler (Steinsland 2000,52). These characteristics can also be seen in their functions in pre-Christian Scandinavian religions and in their relationship with rulers. As previously mentioned, initiation seems to have played a major role in pre-Christian Scandinavian religions, and it seems probable that the elective king was initiated to Óðinn, the god of initiation, as is seen with many rulers (Schjødt 2008; Schjødt 2012b, 74-6). The fact that Óðinn is seen as the progenitor of the jarlar of Hladir and almost all ruler families in the Anglo-Saxon area may be due to his having at some point been the personal god for the duces. This relationship may then have evolved into Óðinn being the progenitor for some of these ruler families (Schjødt 2012b, 76-9), which seems to be the aspect of rulership thematised in the sacrifice of King Víkarr.

Freyr, however, was a fertility god, and the god of sexuality and rulership (Steinsland 2005, 143-63). He seems from the outset to have been connected to genealogies as the god who maintained the fertility of the 
land, and thus the prosperity and wealth of society (Schjødt 2010, 185). This aspect of rulership seems to have been thematised in the sacrifice of King Dómaldi. Furthermore, Terry Gunnell (2000) has proposed that the year in pre-Christian Scandinavia was divided into two spheres. Winter was dedicated to the female powers; summer was controlled by the masculine powers. The relationship between these two gods and their relationship with rulership seems to be structural:

$\begin{array}{ll}\text { Óðinn } & \text { Freyr } \\ \text { war } & \text { fertility } \\ \text { violence } & \text { peace } \\ \text { duces } & \text { reges } \\ \text { summer } & \text { winter }\end{array}$

As we shall see in what follows, this relationship can also be found in preChristian Hawaiian ruler ideology.

In pre-Christian Hawaii double rulership can be seen in the ritual cycle, which was divided in two, much like it has been suggested in connection with pre-Christian Scandinavia. Four of the months were dedicated to the fertility god Lono, the god of horticulture, growth, and life in general. One of Lono's bodies was the gourd, evoking images of pregnancy and femininity. Eight months were dedicated to the war god Kū, god of the alii, violence, and human sacrifice, and very much a masculine god. The four months dedicated to Lono were called the Makahiki-festival, a festival with carnival-like undertones, during which violence and killing were prohibited and sexuality, orgies, feasting, and merrymaking took over. This meant that the regular ruler took a back seat and handed his power over to Lono (Bellah 2011, 200-1; Valeri 1985, 207-19).

The ritual cycle started with the collection of taxes, which was followed by four days of festivities, dance, and orgies, where work and everything to do with the normal ruler and Kù was kapu. Then an idol of Lono was prepared for a circumambulation of the island for the collection of first fruit. This happened in an initiation-like ritual called hānai pū, in which the ruler surrendered his power to Lonomakua (provider-Lono) by hanging a necklace of whale teeth called a niho palaoa around Lonomakua's neck - a symbol of rulership (Valeri 1985, 207-8).

During the Makahiki-festival the normal order of the ruler and the alii was suspended, and an order of the people held sway. Only pigs were allowed to be sacrificed, but during the other eight months of the year, when the normal 
ruler held power, human sacrifice to the war god Kū in the luakini-temple was the central ritual (Schjødt, forthcoming). This ritual was legitimising for the ruler, and, as has already been said, he was the only one who could authorise human sacrifice. This was also the time when wars were fought and when death and violence were imminent threats.

The structural relationship which we saw in pre-Christian Scandinavia can thus also be found in pre-Christian Hawaii:

$\begin{array}{ll}\text { Kū } & \text { Lono } \\ \text { the ruler } & \text { Lonomakua } \\ \text { alii } & \text { the people } \\ \text { death } & \text { sexuality } \\ \text { hierarchy } & \text { equality } \\ \text { violence } & \text { peace }\end{array}$

\section{Conclusion}

This descriptive comparison between pre-Christian Scandinavia and preChristian Hawaii seems to show one thing clearly: a relationship exists between the ruler's position in society and its religion and structure. It also suggests tendentious similarities between the way this relationship is seen in pre-Christian Scandinavia and pre-Christian Hawaii. Do we indeed need to nuance Bellah's typology then? The comparative analyses above suggest this may be necessary. In any case, the strictly egalitarian structure of tribal society, with small tribes of roughly 150 people, does not fit any of the above societies, but neither do the very stratified urban city-states of archaic society. We begin to see stratification in both pre-Christian Scandinavia and pre-Christian Hawaii, but urbanisation simply does not happen before Christianity. This suggests a society between the tribal and the archaic. This crux seems to be found in the religious and ideological material of both societies as well.

In this article I have aimed to open a discussion concerning the possible category of chiefdom religion, rather than irrefutably to prove that such a category must be established. However, I think it is eminently plausible. I have also sought to illustrate the usefulness of cultural evolutionary theory ${ }^{12}$ in the reconstruction of past religions. It can be utilised to optimise

12 Among other things, Bellah's specific theory has been criticised for not being grounded in evolution (see Assmann 2012) and not engaging properly with other evolutionary theories. I cannot here delve into all the criticisms of Bellah (see Stausberg (2014) for an overview of the reception of Bellah's theory). 
the models that we work with in our reconstruction, for example, of preChristian Scandinavian religions, and if a larger scale comparative study into such religions were to be made, it might help fill out the textual lacunae in mythologies such as the Slavic or the Baltic, where very many sources have been lost, by creating a larger scale model of this type of religion. An illustration (Fig. 1) of the typologisation used in this article will further the understanding of this usefulness (see also Nygaard 2014; 2015).

The usefulness of cultural evolutionary theory is also apparent in comparative studies. It makes it possible to construct typological comparisons that might otherwise seem far-fetched (cf. Fig. 1). This is most definitely the case with the comparisons in this article, but, as I have argued, this comparison is possible because the religions in question, however far apart geographically and temporally, seem to belong to the same cultural evolutionary type of religion: they show similarities in religious aspects such as the ruler's position in society, his relationship to sacrifice, different types of gods, and the relationship of these gods to war and fertility. It could be argued that this is just a matter of coincidence and that such tendentious similarities carry no real weight in drawing conclusions. If such criticism is to be countered, further studies into the possible category of chiefdom religion, and further comparative studies based on cultural evolutionary theory, will be needed (cf. Bulbulia et al. 2013).

Comparative studies of other societies that may have had chiefdom religions are one such area to investigate, and potential societies to study could be the early Greek polis states $c$. $800 \mathrm{CE}$. Here, societal structures were very similar to what we see in pre-Christian Scandinavia and pre-Christian Hawaii, with many more or less autonomous societies centred around and ruled from the local akropoleis. The Celtic Hallstatt and La Tène cultures also seem to merit similar investigation, along with several Polynesian societies and African kingdoms. Comparative studies of this kind may help create the useful models mentioned above.

SIMON NYGAARD is PhD Fellow at the Department of the Study of Religion, Aarhus University, Denmark. Email: sn@cas.au.dk. 
Bibliography

\section{Sources}

Bede Historia Ecclesiastica Gentis Angolorum

1969 Bertram Colgrave and R. A. B. Mynors (eds and trans.) Bede's Ecclesiastical History of the English People. Oxford: Clarendon Press.

Caesar De Bello Gallico

1970 H. J. Edwards (ed. and trans.) The Gallic War. London: William Heinemann Ltd \& Cambridge, Massachusetts: Harvard University Press. (The Loeb Classical Library.)

Eddic Poems

1936 Gustav Neckel (ed.) Edda: Die Lieder des Codex regius nebst verwandten Denkmälern. Band 1. Text. 3. durchgesehene Auflage. Heidelberg: C. Winter.

Eyvindr skáldaspillir Háleygjatal

2012 Russell Poole (ed. and trans.) In Skaldic Poetry of the Scandinavian Middle Ages: Vol. 1: Poetry from the Kings' Sagas 1: From Mythical Times to c. 1035. Diana Whaley (ed.): 195-212. Turnhout: Brepols.

Frreyinga saga

2006 Olafur Halldórsson (ed.) Færeyinga saga, Ólafs saga Odds. Íslenzk Fornrit, 25. Reykjavík: Hið Íslenzka Fornritafélag.

Gunnars páttr Helmings

1860 Guðbrandur Vigfússon and C. R. Unger (eds) In Flateyjarbók: En samling af norske konge-sagaer med indskudte mindre fortællinger om begivenheder $i$ og udenfor Norge samt annaler: Vol I, 332-9. Christiania: Malling.

Gautreks saga

1944 Guðni Jónsson and Bjarni Vilhjálmsson (eds) In Fornaldarsögur Norðurlanda: Vol III, 1-43. Reykjavik: Íslendingasagnaútgáfan.

Historia Norwegix

2003 Inger Ekrem and Lars Boje Mortensen (eds) and Peter Fisher (trans.) Historia Norwegiz. Copenhagen: Museum Tusculanum Press.

Rigveda

2001 Ravi Prakash Arya \& K. L. Joshi (eds and trans.) Rgveda Samhitā: Sanskrit Text, English Translation, Notes $\mathcal{E}$ Index of Verses. 4 vols. Parimal Sanskrit Series 45. Delhi: Parimal Publications.

Saxo Grammaticus Gesta Danorum

2005 Karsten Friis-Jensen (ed.) and Peter Zeeberg (trans.). Saxo Grammaticus: 
Gesta Danorum. Danmarkshistorien. 2 vols. København: Det Danske Sprog- og Litteraturselskab \& Gads Forlag.

Snorri Sturluson Edda: Prologue and Gylfaginning

2005 Anthony Faulkes (ed.), 2nd edition. London: Viking Society for Northern Research.

Tacitus Germania

1970 E. H. Warmington (ed.) and M. Hutton (trans.). Tacitus: Agricola, Germania, Dialogus, 1. London: William Heinemann Ltd \& Cambridge, Massachusetts: Harvard University Press. (The Loeb Classical Library.)

Vellakla Einarr skálaglamm Helgason

2012 Edith Marold (ed. and trans.) In Skaldic Poetry of the Scandinavian Middle Ages: Vol. 1: Poetry from the Kings' Sagas 1: From Mythical Times to c. 1035. Ed. Diana Whaley (ed.): 280-329. Turnhout: Brepols.

Vọlsunga saga

1943 Guðni Jónsson and Bjarni Vilhjálmsson (eds) In Fornaldarsögur Norðurlanda: Vol I, 1-92. Reykjavik: Íslendingasagnaútgáfan.

Ynglinga saga Snorri Sturluson

1979 Bjarni Aðalbjarnarson (ed.) In Heimskringla: Vol I, 9-83. Íslenzk Fornrit, 26-28. Reykjavík: Hið Íslenzka Fornritafélag.

Ynglingatal Pjóðólfr ór Hvini,

2012 Edith Marold (ed. and trans.) In Skaldic Poetry of the Scandinavian Middle Ages: Vol. 1: Poetry from the Kings' Sagas 1: From Mythical Times to c. 1035. Diana Whaley (ed.): 3-59. Turnhout: Brepols.

\section{Literature}

\section{Andrén, Anders}

2014 Tracing Old Norse Cosmology: The World Tree, Middle Earth, and the Sun in Archaeological Perspectives. Lund: Nordic Academic Press.

\section{Assmann, Jan}

2006 Religion and Cultural Memory: Ten Studies. - Rodney Livingstone (trans). Stanford: Stanford University Press.

2012 Cultural Memory and the Myth of the Axial Age. - Robert N. Bellah \& Hans Joas (eds), The Axial Age and Its Consequences, 366-407. Cambridge \& London: The Belknap Press of Harvard University Press.

\section{Baetke, Walter}

1964 Yngvi und die Ynglingar: Eine quellenkritische Untersuchung über das nordische 'Sakralkönigtum'. Berlin: Akademie-Verlag. 


\section{Bellah, Robert N.}

1964 Religious Evolution. - American Sociological Review 29 (3), 358-74.

2011 Religion in Human Evolution: From the Palaeolithic to the Axial Age. Cambridge \& London: The Belknap Press of Harvard University Press.

\section{Brink, Stefan}

1996 Political and Social Structures in Early Scandinavia: A Settlementhistorical Pre-study of the Central Place. - Tor 28, 235-81.

1997 Political and Social Structures in Early Scandinavia II: Aspects of Space and Territoriality - The Settlement District. - Tor 29, 389-437.

Bulbulia, Joseph et al.

2013 The Cultural Evolution of Religion - Peter J. Richerson \& Morten H. Christiansen (eds.), Cultural Evolution: Society, Technology, Language, and Religion, 381-404. Cambridge, MA: The MIT Press.

\section{Christensen, Tom}

2012 Lejre and Roskilde. - Stefan Brink, in collaboration with Neil Price (eds), The Viking World, 121-5. London \& New York: Routledge.

\section{Donald, Merlin}

2001 A Mind so Rare. The Evolution of Human Consciousness. New York \& London: W.W. Norton and Company.

\section{Egeler, Matthias}

2013 Celtic Influences in Germanic Religion: A Survey. Münchner Nordistische Studien 15. München: Utz Verlag.

\section{Elmevik, Lennart}

2003 Freyr, Frey och Freyfaxi - Studia anthroponymica Scandinavica 21, 5-13.

\section{Enright, Michael J.}

1996 Lady with a Mead Cup: Ritual, Prophecy and Lordship in the European Warband from La Tène to the Viking Age. Dublin: Four Courts Press.

\section{Frazer, James George}

1890 The Golden Bough: A Study in Comparative Religion. 2 vols. London: Macmillian and Co.

\section{Frog \& Jonathan Roper}

2011 Verses versus the 'Vanir': Response to Simek's 'Vanir Obituary'. - RMN Newsletter 2, 29-37.

\section{Geertz, Clifford}

1973 The Interpretation of Cultures. New York: Basic Books.

\section{Glob, Peter Vilhelm}

1969 The Bog People: Iron Age Man Preserved. London: Faber and Faber. 


\section{Goldman, Irving}

1970 Ancient Polynesian Society. Chicago \& London: University of Chicago Press.

\section{Gunnell, Terry}

2000 The Season of the Dísir: The Winter Nights, and the Dísablót in Early Medieval Scandinavian Belief. - Cosmos 16, 117-49.

\section{Hopkins, Joseph S.}

2012 Goddesses Unknown I: Njorun and the Sister-Wife of Njorðr. - RMN Newsletter 5, 39-44.

\section{Hultgård, Anders}

2001 Menschenopfer. - Heinrich Beck, Dieter Geuenich \& Heiko Steuer (eds.), Reallexikon der Germanischen Altertumskunde 19, 534-45. Berlin \& New York: De Gruyter.

\section{Hyenstrand, Åke}

1974 Centralbygd-Randbygd. Strukturella, ekonomiska och administrativa huvudlinjer i mellansvensk yngre järnålder. Acta universitatis Stockholmiensis. Studies in North-European Archaeology 5. Stockholm.

1996 Lejonet, draken och korset. Sverige 500-1000. Lund: Studentlitteratur.

\section{Höfler, Otto}

1952 Germanisches Sakralkönigtum I. Tübingen: M. Niemeyer.

\section{Jensen, Hans Jørgen Lundager}

2013 Robert Bellah, religion og menneskelig evolution. - Religionsvidenskabeligt Tidsskrift 60, 11-31.

\section{Kirch, Patrick Vinton}

1984 The Evolution of Polynesian Chiefdoms. Cambridge: Cambridge University Press.

\section{Lang, Bernhard}

2013 Agerbrugeren, den intellektuelle og individet. Præsentation og fortolkning af religiøs evolution efter Robert Bellah. Med en annoteret bibliografi over de historiske stadier, Bellah-style. - Religionsvidenskabeligt Tidsskrift 60, 32-56.

\section{Malo, David}

1903 Hawaiian Antiquities (Moolelo Hawaii). - Dr. N. B. Emerson (trans). Honolulu: Hawaiian Gazette C., Ltd.

\section{McKinnell, John \& Rudolf Simek \& Klaus Düwel}

2004 Runes, Magic and Religion: A Sourcebook, Studia Medievalia Septentrionalia 10 Vienna: Fassbaender. 


\section{McTurk, Rory}

1974-77 Sacral Kingship in Ancient Scandinavia. A Review of Some Recent Writings. -Saga-Book of the Viking Society 19, 139-69.

\section{North, Richard}

1997 Heathen Gods in Old English Literature, Cambridge: Cambridge University Press.

\section{Näsström, Britt-Mari}

1995 Freyja: The Great Goddess of the North. Lund: University of Lund.

\section{Nygaard, Simon}

2013 Review: Catharina Raudvere \& Jens Peter Schjødt, eds. More than Mythology. Narratives, Ritual Practices and Regional Distribution in PreChristian Scandinavian Religions. - Religionsvidenskabeligt Tidsskrift 60, 137-9.

2014 Religion og sakrale herskere i det førkristne Norden: Religionstypologisering, kulturevolution, komparation og høvdingedømmereligion. Unpublished Master's thesis, Aarhus University.

2015 Religion and Sacral Rulers in the Pre-Christian North: Typologisation of Religion, Cultural Evolution, Comparison and Chiefdom Religion. - RMN Newsletter 9, 143-45.

\section{Petersen, Anders Klostergaard}

2013 Aksetid, det aksiale, aksialisering. Om Robert Bellah \& Hans Joas, Eds., The Axial Ages and its Consequences - Religionsvidenskabeligt Tidsskrift 60, 57-74.

\section{Picard, Eve}

1991 Germanisches Sakralkönigtum? Quellenkritische Studien zur Germania des Tacitus und zur altnordischen Uberlieferung. Skandinavistischen Arbeiten 12. Heidelberg: C. Winter.

\section{Price, Neil}

2012 Mythic Acts. Material Narratives of the Dead in Viking Age Scandinavia. - Catharina Raudvere \& Jens Peter Schjødt (eds), More than Mythology. Narratives, Ritual Practices and Regional Distribution in Pre-Christian Scandinavian Religions, 13-46. Lund: Nordic Academic Press.

\section{Rappaport, Roy}

1979 Ecology, Meaning and Religion. Richmond, CA: North Atlantic Books.

\section{Roesdahl, Else}

2010 The Vikings. London: Penguin Books.

\section{Schjødt, Jens Peter}

1990 Det sakrale kongedømme i det førkristne Skandinavien. - Chaos 13, 48-68. 
2008 Initiation Between Two Worlds: Structure and Symbolism in Pre-Christian Scandinavian Religion. Odense: The University of Southern Denmark Press.

2010 Ideology of the Ruler in Pre-Christian Scandinavia: Mythic and Ritual Relations. - Viking and Medieval Scandinavia 6, 161-94.

2012a Reflections on Aims and Methods in the Study of Old Norse Religion. - Catharina Raudvere \& Jens Peter Schjødt (eds.), More than Mythology. Narratives, Ritual Practices and Regional Distribution in Pre-Christian Scandinavian Religion, 263-87. Lund: Nordic Academic Press.

2012b Óðínn, Pórr and Freyr: Functions and Relations. - Merril Kaplan \& Timothy R. Tangherlini (eds.), News From Other Worlds: Studies in Nordic Folklore, Mythology and Culture: In Honor of John F. Lindow, 61-91. Berkeley \& Los Angeles: North Pinehurst Press.

2014 New Perspectives on the Vanir Gods in Pre-Christian Scandinavian Mythology Religion - Timothy R. Tangherlini (ed), Nordic Mythologies: Interpretations, Intersections and Institutions, 19-34. Berkeley \& Los Angeles: North Pinehurst Press.

Forthcoming Pre-Christian Religion of the North and the Need for Comparativism: Reflections on Why, How, and With What We Can Compare. - Pernille Hermann, Stephen Mitchell and Jens Peter Schjødt with Amber Rose (eds.), Old Norse Mythology in Comparative Perspective, Publication of the Milman Parry Collection of Oral Literature. Cambridge, Massachusetts: Harvard University Press.

\section{Schlesinger, Walter}

1956 Über germanisches Heerkönigtum. - Theodor Mayer (ed.): Das Königtum. Seine geistigen und rechtlichen Grundlagen, Vorträge und Forschungen 3. Lindau und Konstanz: Jan Thorbecke Verlag.

\section{Simek, Rudolf}

2010 The Vanir: An Obituary. - RMN Newsletter 1, 10-19.

\section{Skre, Dagfinn}

2012 The Development of Urbanism in Scandinavia. - Stefan Brink, in collaboration with Neil Price (eds), The Viking World, 83-93. Oxon \& New York: Routledge.

\section{Stausberg, Michael}

2014 Bellah's Religion in Human Evolution. A Post-Review. - Numen 61, 281-99.

\section{Steinsland, Gro}

1991 Det hellige bryllup og norrøn kongeideologi. En undersøkelse av hierogamimyten i Skírnismál, Ynglingatal, Háleygjatal og Hyndluljód. Larvik: Solum Forlag.

2000 Den hellige kongen. Oslo: Pax Forlag A/S.

2005 Norrøn religion. Myter, riter, samfunn. Oslo: Pax Forlag A/S. 


\section{Ström, Folke}

1954 Diser, nornor, valkyrjor. fruktbarhedskultur och sakralt kungadöme i norden. Kungl. vitterhets historie och antikvitets akademiens handlingar. Filologisk-filosofiska serien 1. Stockholm: Almqvist \& Wiksell.

Ström, Å. V.

1959 The King God and His Connection With Sacrifice in Old Norse Religion. - G. Widengren et el (eds), In The Sacral Kingship Contributions of the Central Theme of the VIIIth International Congress for the History of Religions (Rome, April 1955), 702-15. Leiden: E. J. Brill.

\section{Sundqvist, Olof}

2002 Freyr's Offspring. Historia Religionum 21. Uppsala: Acta Universitatis Upsaliensis.

2012 'Religious Ruler Ideology' in Pre-Christian Scandinavia. A Contextual Approach. - Catharina Raudvere \& Jens Peter Schjødt, More than Mythology. Narratives, Ritual Practices and Regional Distribution in Pre-Christian Scandinavian Religion, 225-61. Lund: Nordic Academic Press.

2016 An Arena for Higher Powers: Ceremonial buildings and religious strategies for rulership in Late Iron Age Scandinavia. Leiden: Brill.

\section{Tolley, Clive}

2011 In Defence of the Vanir. - RMN Newsletter 2, 20-9.

Trigger, Bruce G.

2003 Understanding Early Civilizations: A Comparative Study. Cambridge: Cambridge University Press.

\section{Turner, Jonathan \& Alexandra Maryanski}

2008 On the Origins of Societies by Natural Selection, Boulder: Paradigm Publishers.

\section{Valeri, Valerio}

1985 Kingship and Sacrifice: Ritual and Society in Ancient Hawaii. Chicago \& London: The University of Chicago Press.

\section{Vikstrand, Per}

2001 Gudarnas platser. Förkristna ortnamn i Mälarlandskapen. Acta academiae regiae Gustavi Adolphi 77. Studier till en svensk ortnamnsatlas 17, Thorsten Andersson (ed.). Uppsala.

\section{Von Friesen, Otto}

1932-34 Har det nordiska kungadömet sakralt ursprung? - Saga och Sed (1932-34), 15-34. 


\section{Appendix: Figure 1.}

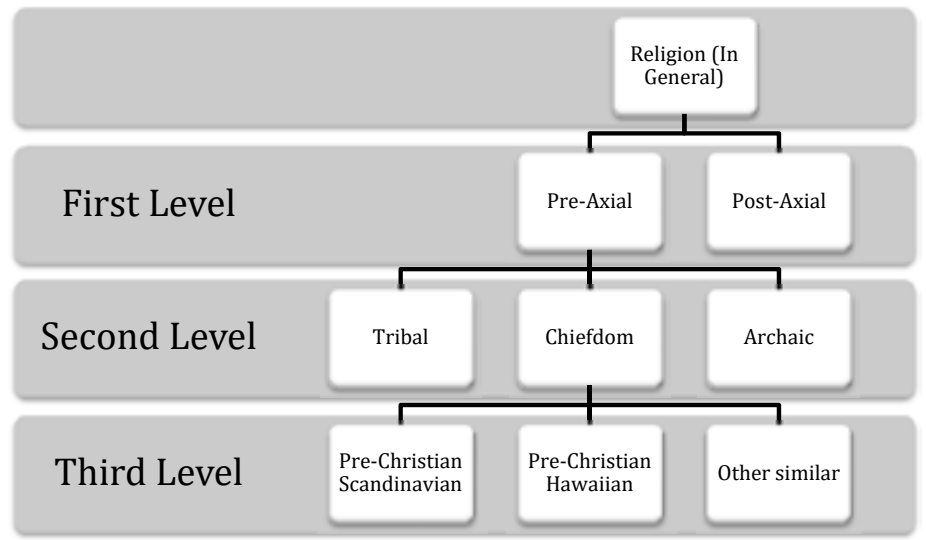


